\title{
Genetic Analysis of Phytophthora nicotianae Populations from Different Hosts Using Microsatellite Markers
}

\author{
Antonio Biasi, Frank N. Martin, Santa O. Cacciola, Gaetano Magnano di San Lio, \\ Niklaus J. Grünwald, and Leonardo Schena
}

First, fourth, and sixth authors: Dipartimento di Agraria, Università Mediterranea di Reggio Calabria, Località Feo di Vito, 89122 Reggio Calabria, Italy; second author: United States Department of Agriculture-Agricultural Research Service (USDA-ARS), 1636 East Alisal Street, Salinas, CA 93905; third author: Dipartimento di Agricoltura, Alimentazione e Ambiente, Università degli Studi, Via S. Sofia 100, 95123 Catania, Italy; and fifth author: Horticultural Crops Research Laboratory, USDA-ARS, Corvallis, OR.

Accepted for publication 15 April 2016.

\begin{abstract}
Biasi, A., Martin, F. N., Cacciola, S. O., Magnano di San Lio, G., Grünwald, N. J., and Schena, L. 2016. Genetic analysis of Phytophthora nicotianae populations from different hosts using microsatellite markers. Phytopathology 106:1006-1014.

In all, 231 isolates of Phytophthora nicotianae representing 14 populations from different host genera, including agricultural crops (Citrus, Nicotiana, and Lycopersicon), potted ornamental species in nurseries (Lavandula, Convolvulus, Myrtus, Correa, and Ruta), and other plant genera were characterized using simple-sequence repeat markers. In total, 99 multilocus genotypes (MLG) were identified, revealing a strong association between genetic grouping and host of recovery, with most MLG being associated with a single host genus. Significant differences in the structure of populations were revealed but clonality prevailed in all populations. Isolates from Citrus were found to be genetically related regardless of

their geographic origin and were characterized by high genetic uniformity and high inbreeding coefficients. Higher variability was observed for other populations and a significant geographical structuring was determined for isolates from Nicotiana. Detected differences were related to the propagation and cultivation systems of different crops. Isolates obtained from Citrus spp. are more likely to be distributed worldwide with infected plant material whereas Nicotiana and Lycopersicon spp. are propagated by seed, which would not contribute to the spread of the pathogen and result in a greater chance for geographic isolation of lineages. With regard to ornamental species in nurseries, the high genetic variation is likely the result of the admixture of diverse pathogen genotypes through the trade of infected plant material from various geographic origins, the presence of several hosts in the same nursery, and genetic recombination through sexual reproduction of this heterothallic species.
\end{abstract}

In a recent survey to query the scientific community for their ranking of plant-pathogenic oomycete species based on both scientific and economic importance, Phytophthora nicotianae Breda de Haan ( $P$. parasitica Dastur) was listed eighth, and it is likely to gain importance in the foreseeable future (Kamoun et al. 2015). This oomycete is a soilborne plant pathogen with a wide host range comprising more than 250 plant genera (Cline et al. 2008; Panabières et al. 2016). It is particularly known for its damage on the genera Nicotiana and Citrus, as the causal agent of black shank and citrus root rot and gummosis, respectively, but it is responsible for heavy losses on many other economically important crops such as fruit trees and vegetable and ornamental crops (Erwin and Ribeiro 1996; Ippolito et al. 2004; Moralejo et al. 2009). A number of surveys revealed that $P$. nicotianae is one of the most common pathogens in nurseries, especially on ornamental plants, where it commonly completes several disease cycles per year due to the repeated culture of different host species (Cacciola et al. 1997, 2001; Moralejo et al. 2009; Pane et al. 2005; Prigigallo et al. 2015, 2016; Reichard and White 2001). This pathogen produces various types of propagules, including sporangia, chlamydospores, and oospores, which can be formed when the mycelium of sexually

Corresponding author: L. Schena; E-mail address: 1schena@unirc.it

*The $\boldsymbol{e}$-Xtra logo stands for "electronic extra" and indicates that two supplementary tables are published online.

http://dx.doi.org/10.1094/PHYTO-11-15-0299-R

This article is in the public domain and not copyrightable. It may be freely reprinted with customary crediting of the source. The American Phytopathological Society, 2016. compatible mating types (A1 and A2) comes into contact. Sporangia can germinate directly as mycelium or differentiate into zoospores that are motile. Oospores constitute a potential source of genetic variation and, with resting chlamydospores, contribute to survival under unfavorable conditions in soil or within infected plant tissues.

$P$. nicotianae might be considered a candidate species for studying migration pathways of Phytophthora spp. and other soilborne pathogens on a global scale. Its polyphagia and prominence in nurseries of potted ornamentals and fruit tree species are important factors that favor a rapid distribution on a global scale. Indeed, the global nursery trade represents one of the most efficient diffusion pathways for soilborne pathogens (Abad et al. 2014; Jung et al. 2016; Moralejo et al. 2009; Olson and Benson 2011; Parke and Grünwald 2012). Furthermore, the ornamental industry extensively uses antioomycete chemicals that can hide the presence of the pathogen and increase the risk of rapid spread of resistant strains to new areas (Brasier 2008; Olson et al. 2013). Moreover, P. nicotianae will likely benefit from the warming climate because its host range is generally similar to other species of prime economic importance such as $P$. infestans, $P$. capsici, and $P$. citrophthora but generally requires warmer conditions than these other species (Erwin and Ribeiro 1996; Kamoun et al. 2015).

Despite the great economic relevance of $P$. nicotianae, significant information on the biology and ecology of this pathogen is still lacking. Few studies are currently available on the genetic structure of $P$. nicotianae populations and most of them were focused on either specific hosts (mainly tobacco) or geographic areas. The characterization of seven different populations from tobacco using a random amplified polymorphic DNA polymerase chain reaction (RAPD-PCR) approach revealed a high level of variability within a 
population but no distinct genotypes were associated with specific populations (Zhang et al. 2003). The same technique was used to differentiate isolates causing black shank from isolates that did not cause this disease (Zhang et al. 2001) and to identify markers linked to the dominant black shank resistance gene (Johnson et al. 2002a). Amplified fragment length polymorphism analysis enabled the identification of six clonal lineages in a population from different floricultural hosts and production sites (Lamour et al. 2003). Sullivan and coworkers (2010) found that tobacco populations were able to evolve and adapt to the host genotypes deployed in the field.

Recently, polymorphic mitochondrial and nuclear regions were utilized to study genetic diversity in a worldwide collection of P. nicotianae isolates (Mammella et al. 2011, 2013). Singlenucleotide polymorphisms (SNP) detected in both mitochondrial and nuclear markers revealed a high level of dispersal of isolates and a low geographic clustering of populations. Nonetheless, a specific association was observed between the host of origin and genetic cluster for some hosts and, thus, it was suggested that nursery populations played an important role not only for increasing genetic recombination within the species but also in terms of providing a means of dispersal of genotypes worldwide via movement of infected plant material. However, mitochondrial analyses conducted with an outcrossing species such as $P$. nicotianae may produce incomplete results, and the three nuclear markers investigated were not variable enough to provide discrimination among closely related isolates (Mammella et al. 2013).

Microsatellites, or simple-sequence repeats (SSR), are largely accepted as a powerful molecular tool for investigating intraspecific variability in a large number of eukaryotic species (Oliveira et al. 2006; Gonthier et al. 2015). In oomycetes, SSR have been used in a number of important applications, including diagnosis and determination of mating type, genetic structure and disease dynamics, and population genetics (Garnica et al. 2006; Schena et al. 2008). Relevant studies have been conducted on several Phytophthora spp., including P. infestans (Cooke and Lees 2004; Goss et al. 2014; Li et al. 2013), P. alni (Ioos et al. 2007), P. ramorum (Goss et al. 2009; Prospero et al. 2007), P. sojae (Stewart et al. 2014), and P. capsici (Hu et al. 2013), as well as P. plurivora, P. multivora, and P. pini (Schoebel et al. 2013, 2014). Furthermore, a set of nine specific SSR markers for P. nicotianae has been recently developed (Biasi et al. 2015).

The objective of the present study was to genotype isolates of $P$. nicotianae obtained from different hosts and geographic localities using recently validated SSR markers (Biasi et al. 2015) to determine whether there were associations of particular genotypes with host of recovery or location of collection.

\section{MATERIALS AND METHODS}

Isolate sampling, identification, and mating type determination. In total, 231 isolates of $P$. nicotianae were obtained from soil, roots, and basal stem samples from different hosts and geographic regions (Supplementary Table S1). Isolates were sampled from six continents, although most of them were sourced from Italy $(n=163)$, Vietnam $(n=36)$, the United States $(n=16)$, and Australia $(n=6)$. Isolates were mainly obtained from Citrus spp. $(n=90)$, several horticultural and ornamental crops $(n=121)$, and Nicotiana spp. $(n=20)$. All isolates from ornamental cultures were sampled from potted plants in nurseries.

Isolates were identified by means of morphological criteria and sequencing of the internal transcribed spacer (ITS) region of the ribosomal DNA. For ITS sequencing, total DNA was extracted as described by Ippolito et al. (2002), amplified with the universal primers ITS6 and ITS4, and sequenced with the same primers using an external service (Macrogen). Isolates were determined to be $P$. nicotianae based on their phylogenetic clustering with reference isolates of the species (Robideau et al. 2011). Mating type was determined by pairing each isolate with known A1 and A2 strains on V8 juice agar medium, as described by Erwin and Ribeiro (1996).
SSR genotyping. Nine validated polymorphic SSR markers were utilized to genotype isolates (Biasi et al. 2015). Forward primers were labeled with the fluorescent dyes 6-FAM or HEX, while all reverse primers were modified with a 5' PIG tail "GTTT" to reduce the phenomenon of stutter peaks (Brownstein et al. 1996). Eight of the nine forward primers were labeled with two different fluorophores (HEX and 6-FAM) and assembled into four multiplex PCR sets for simultaneous amplicon sizing (Table 1). Reaction mixtures and amplification conditions were as described by Biasi et al. (2015). The data were collected using the software Data Collection (v.2.0; Applied Biosystems) and analyzed by Gene Mapper (v. 4.1; Applied Biosystems) to derive the size of the labeled DNA fragments using the GeneScan 500 LIZ Size Standard (Life Technologies).

Data analysis. Analysis focused on multilocus genotypes (MLG) to infer genotypic diversity in populations. To perform analyses, isolates were grouped according to the genus of the host from which they were obtained. The R package poppr (Kamvar et al. 2014) was used to calculate basic population statistics, including (i) Stoddart and Taylor's index, $G=1 / \Sigma_{i} p^{2}$, where $p_{i}$ is the observed frequency of $i$ th genotype (Stoddart and Taylor 1988) and the normalized $G^{\prime}$ index which removes bias due to the sample size (Chen et al. 1994), and it is particularly appropriate when comparing populations showing high diversity; (ii) evenness, $E_{5}=$ $(1 / \lambda)-1 / e^{H^{\prime}}-1$, where $\lambda$ is Simpson's index and $\mathrm{H}^{\prime}$ is ShannonWiener's index; and (iii) Bruvo's distance (Bruvo et al. 2004). $E_{5}$ is a preferred index of evenness because it is less dependent on the number of genotypes in a sample (Grünwald et al. 2003). Bruvo's distance enabled the measurement of the genetic distances among isolates by calculating the minimum distance across all combinations of possible pairs of alleles at a single locus and then averaging that distance across all loci. Bruvo's distance was utilized to construct minimum spanning networks (MSN) to graphically show the possible evolutionary relationships among MLG. MSN contain a set of pairwise distances that describe the degree of dissimilarity among individuals and allow inference of population structure analogous to a phylogenetic analysis (Ronquist and Huelsenbeck 2003; Salipante and Hall 2011). Lynch's distances (Lynch 1990) was used to perform a principal coordinate analysis (PCA) using the R package POLYSAT (Clark and Jasieniuk 2011). Lynch's distance is a simple measure of similarity and corresponds to two times the number of common alleles divided by the total number of alleles of the two genotypes considered.

Furthermore, $F$ statistics $\left(F_{\text {IS }}\right.$ and $\left.F_{\mathrm{ST}}\right)$ were calculated using the software GENODIVE (Meirmans and van Tienderen 2004), in order to quantify the level of divergence between observed and expected heterozygosity. More specifically, the inbreeding coefficient $F_{\text {IS }}$ was used to scale the deviation of genotypic frequencies from expected panmictic frequencies in terms of heterozygous deficiency or excess. The fixation index $F_{\mathrm{ST}}$ was used to examine the overall genetic differentiation among populations.

TABLE 1. Number of alleles, range of amplicon size, and number of repeats detected in the complete panel of Phytophthora nicotianae isolates analyzed in the present study using a validated set of nine simple-sequence repeats ${ }^{\mathrm{a}}$

\begin{tabular}{lccrr}
\hline Locus $^{\mathrm{b}}$ & $\begin{array}{c}\text { Number of } \\
\text { alleles }\end{array}$ & Dye & $\begin{array}{r}\text { Product } \\
\text { size (bp) }\end{array}$ & $\begin{array}{c}\text { Number of } \\
\text { repeats }\end{array}$ \\
\hline P5 $_{(1)}$ & 13 & HEX & $186-266$ & $4-24$ \\
P15 $_{(2)}$ & 14 & FAM & $66-123$ & $8-27$ \\
P17 $_{(1)}$ & 14 & FAM & $102-165$ & $10-31$ \\
P643 $_{(3)}$ & 17 & FAM & $148-202$ & $9-36$ \\
P788 $_{(3)}$ & 7 & HEX & $127-143$ & $9-17$ \\
P1129 $_{(4)}$ & 7 & HEX & $133-163$ & $7-17$ \\
P1509 $_{(5)}$ & 23 & FAM & $116-176$ & $12-42$ \\
P2039 $_{(4)}$ & 4 & FAM & $99-120$ & $5-12$ \\
P2040 $_{(2)}$ & 7 & HEX & $149-167$ & $8-14$ \\
\hline
\end{tabular}

a Biasi et al. (2015).

b Each number in parentheses indicates the markers paired for multiplex polymerase chain reaction. 


\section{RESULTS}

SSR genotyping. Considering all possible combinations among investigated isolates and the nine SSR loci, only 2 of 2,079 amplicons (locus P1509 for isolates P1495 and M1f1h) could not be sized because no amplification occurred (Supplementary Tables S1 and S2). In total, 99 MLG were detected among the 231 isolates and most genotypes were observed only once or at low frequency. The number of alleles at each locus varied from a minimum of 4 (locus 2039) to a maximum of 23 (locus P1509) while the number of repeats ranged from 4 (locus P5) to 42 (locus P1509) (Table 1).

TABLE 2. List of multilocus genotypes (MLG) characterized in the present study along with host and geographic origin of isolates ${ }^{\mathrm{a}}$

\begin{tabular}{|c|c|c|c|}
\hline MLG & $N^{\mathrm{b}}$ & Host & Geographic origin \\
\hline 1 & 1 & Nicotiana tabacum & Australia \\
\hline 2 & 1 & Myrtus communis & Sardinia \\
\hline 3 & 4 & Lavandula stoechas & Sicily \\
\hline 4 & 1 & L. stoechas & Sicily \\
\hline 5 & 1 & Chamaleucium uncinatum & Apulia \\
\hline 6 & 3 & Convolvulus mauritanicus & Apulia \\
\hline 7 & 1 & C. mauritanicus & Apulia \\
\hline 8 & 1 & C. mauritanicus & Apulia \\
\hline 9 & 1 & Hebe $\times$ Veronica myrtifolia & Sicily \\
\hline 10 & 1 & L. officinalis & Apulia \\
\hline 11 & 1 & L. officinalis & Apulia \\
\hline 12 & 2 & M. communis & Sardinia \\
\hline 13 & 1 & M. communis & Sardinia \\
\hline 14 & 1 & Chamaleucium uncinatum & Sicily \\
\hline 15 & 8 & Ruta graveolens & Sicily \\
\hline 16 & 1 & $R$. graveolens & Sicily \\
\hline 17 & 3 & $\begin{array}{l}\text { Lycopersicon esculentum (2); } \\
\quad \text { R. graveolens (1) }\end{array}$ & Lazio (2); Sicily (1) \\
\hline 18 & 1 & L. esculentum & Lazio \\
\hline 19 & 1 & L. esculentum & Lazio \\
\hline 20 & 2 & Lavandula officinalis & Sicily (1); Liguria (1) \\
\hline 21 & 1 & L. officinalis & Liguria \\
\hline 22 & 1 & Capsicum annum & Spain \\
\hline 23 & 2 & Citrus maxima & Mo Cay \\
\hline 24 & 3 & C. aurantium & Sicily \\
\hline 25 & 1 & C. aurantium & Sicily \\
\hline 26 & 1 & C. aurantium & Sicily \\
\hline 27 & 1 & C. aurantium & Sicily \\
\hline 28 & 1 & C. aurantium & Sicily \\
\hline 29 & 1 & C. aurantium & Tunisia \\
\hline 30 & 1 & C. aurantium & Sicily \\
\hline 31 & 1 & C. aurantium & Sicily \\
\hline 32 & 1 & C. aurantium & Sicily \\
\hline 33 & 1 & Polygala myrtifolia & Liguria \\
\hline 34 & 1 & Lavandula sp. & Apulia \\
\hline 35 & 1 & M. communis & Liguria \\
\hline 36 & 1 & Convolvulus mauritanicus & Apulia \\
\hline 37 & 3 & C. mauritanicus & Apulia \\
\hline 38 & 1 & Lycopersicon esculentum & Spain \\
\hline 39 & 1 & L. esculentum & Lazio \\
\hline 40 & 1 & L. esculentum & Lazio \\
\hline 41 & 1 & L. esculentum & Sicily \\
\hline 42 & 1 & L. esculentum & Lazio \\
\hline 43 & 1 & C. sinensis $\times P$. trifoliata & California \\
\hline 44 & 2 & Lavandula angustifolia & Piedmont \\
\hline 45 & 2 & $\begin{array}{l}\text { Capsicum anпиum }(1) ; \\
\text { M. communis }(1)\end{array}$ & Calabria (1); Sicily (1) \\
\hline 46 & 1 & Lycopersicon esculentum & Chile \\
\hline 47 & 1 & C. аппиит & Calabria \\
\hline 48 & 19 & $\begin{array}{l}\text { Citrus maxima }(18) \\
\text { C. reticulata }(1)\end{array}$ & $\begin{array}{l}\text { Mo Cay (10); Thot } \\
\text { Not (7); Dong Nai (2) }\end{array}$ \\
\hline 49 & 1 & C. sinensis $\times P$. rifoliata & California \\
\hline 50 & 1 & C. maxima & Mo Cay \\
\hline
\end{tabular}

a Numbers within parentheses indicate isolates sharing the same MLG from each host and geographic locality. Sicily, Apulia, Sardinia, Lazio, Liguria, Piedmont, Calabria, and Sardinia are Italian regions and Mo Cay, Dong Nai, Thot Not, Binh Duong, and Cao Phong are Vietnamese provinces.

b Number of isolates.
MLG52 was observed most frequently, because it was shared in 38 isolates, which were all recovered from Citrus spp. (Table 2). In all, 6 of these isolates were collected from three different districts in Vietnam, 1 from the Philippines, and 31 from three Italian regions (27 in Sicily, 3 in Calabria, and 1 in Apulia). Interestingly, the second most numerous MLG (MLG48) was also shared among Citrus strains $(n=19)$, although most of them were obtained from a single host species (Citrus maxima), with a single isolate sampled from $C$. reticulata. All isolates with this MLG were recovered from southern Vietnam. MLG71 and MLG66 were represented by 12 and 11 isolates, respectively, and all isolates of these genotypes were recovered from the same geographic region (Sardinia, Italy) and host

TABLE 2. (continued from preceding column)

\begin{tabular}{|c|c|c|c|}
\hline MLG & $N^{\mathrm{b}}$ & Host & Geographic origin \\
\hline 51 & 1 & C. maxima & Mo Cay \\
\hline 52 & 38 & $\begin{array}{l}\text { C. sinensis } \times P \text {. trifoliata }(1) \\
\text { C. } \text { aurantifolia }(1) \\
\text { C. } \text { aurantium }(23) \\
\text { C. jambhiri }(1) \\
\text { C. maxima }(4) ; \\
\text { C. medica }(8)\end{array}$ & $\begin{array}{l}\text { Sicily (27); Calabria (3); } \\
\text { Binh Duong (2); } \\
\text { Cao Phong (2); Dong } \\
\text { Nai (2); Apulia (1); } \\
\text { Philippines (1) }\end{array}$ \\
\hline 53 & 1 & C. aurantium & Sicily \\
\hline 54 & 1 & C. maxima & Dong Nai \\
\hline 55 & 2 & C. maxima & Dong Nai \\
\hline 56 & 1 & C. sinensis $\times P$. trifoliate & California \\
\hline 57 & 1 & M. communis & Sardinia \\
\hline 58 & 1 & C. aurantium & Syria \\
\hline 59 & 1 & C. aurantium & Apulia \\
\hline 60 & 1 & C. aurantium & Apulia \\
\hline 61 & 1 & C. aurantium & Sicily \\
\hline 62 & 6 & $\begin{array}{l}\text { Lavandula officinalis (4); } \\
\text { P. myrtifolia (2) }\end{array}$ & $\begin{array}{l}\text { Sicily (4); } \\
\text { Liguria (2) }\end{array}$ \\
\hline 63 & 1 & L. officinalis & Sicily \\
\hline 64 & 2 & C. aurantium & Sicily \\
\hline 65 & 6 & $\begin{array}{l}\text { Hebe } \times \text { Veronica } \\
\text { buxifolia }(2) ; \\
\text { L. officinalis }(4)\end{array}$ & Sicily (6) \\
\hline 66 & 11 & M. communis & Sardinia \\
\hline 67 & 1 & M. communis & Sardinia \\
\hline 68 & 1 & M. communis & Sardinia \\
\hline 69 & 3 & M. communis & Sardinia \\
\hline 70 & 1 & M. communis & Sardinia \\
\hline 71 & 12 & M. communis & Sardinia \\
\hline 72 & 1 & M. communis & Sardinia \\
\hline 73 & 1 & Rosmarinus officinalis & Sicily \\
\hline 74 & 2 & $\begin{array}{l}\text { Chamaleucium } \\
\text { uncinatum }(1) \\
\text { L. officinalis }(1)\end{array}$ & Sicily \\
\hline 75 & 5 & Dodonaea purpurea & Sicily \\
\hline 76 & 1 & N. tabacum & Kentucky \\
\hline 77 & 3 & N. tabacum & Virginia \\
\hline 78 & 1 & N. tabacum & Australia \\
\hline 79 & 1 & N. tabacum & Australia \\
\hline 80 & 1 & N. tabacum & Australia \\
\hline 81 & 1 & N. tabacum & Australia \\
\hline 82 & 1 & N. tabacum & Australia \\
\hline 83 & 1 & N. tabacum & Virginia \\
\hline 84 & 1 & N. tabacum & Virginia \\
\hline 85 & 2 & N. tabacum & Virginia \\
\hline 86 & 1 & Rosmarinus sp. & Sicily \\
\hline 87 & 1 & N. tabacum & Kentucky \\
\hline 88 & 1 & N. tabacum & Georgia \\
\hline 89 & 1 & Citrus sp. & Trinidad and Tobago \\
\hline 90 & 1 & N. tabacum & North Carolina \\
\hline 91 & 1 & N. tabacum & Georgia \\
\hline 92 & 1 & N. tabacum & Greece \\
\hline 93 & 1 & N. tabacum & Virginia \\
\hline 94 & 10 & Correa reflexa & Sicily \\
\hline 95 & 1 & C. reflexa & Sicily \\
\hline 96 & 2 & Rosmarinus sp. & Sicily \\
\hline 97 & 1 & Citrus aurantium & Ham Yen \\
\hline 98 & 1 & C. aurantium & Ham Yen \\
\hline 99 & 2 & $\begin{array}{l}\text { C. aurantium }(1) ; \\
\text { C. reticulata }(1)\end{array}$ & $\begin{array}{l}\text { Ham Yen (1), } \\
\text { Cao Phong (1) }\end{array}$ \\
\hline
\end{tabular}


(Myrtus spp.). Similarly, MLG94 was identified in 10 isolates from the same region (Sicily, southern Italy) and host (Correa reflexa).

The great majority of MLG were associated with isolates from a single host genus. Exceptions were observed in MLG17 (Ruta and Lycopersicon), MLG45 (Myrtus and Capsicum), MLG62 (Polygala and Lavandula), MLG65 (Hebe and Lavandula), and ML74 (Chamaleucium and Lavandula).

Fifteen isolates showed unexpected ploidy; that is, more than two alleles were detected in one or more SSR loci. For 14 of the isolates, triploidy was identified in one of five loci (P15, P788, P1129, $\mathrm{P} 1509$, and P2039), while tetraploidy was observed for locus P17 in isolate Ph168; this isolate also was triploid for loci P15 and P1129. All isolates were the only representatives in their MLG (MLG 1, 8, $9,26,29,31,32,33,40,51,53,70,88$, and 92) with the exception of MGL44, which had two isolates collected from the same host and location.

Population genetic analysis. The 231 isolates sampled globally were grouped into 14 populations according to the host genus sampled or into 15 populations by geographic origin to determine whether populations were differentiated by host or geographic origin (Table 3). Analyses revealed a prevalence of clonal reproduction in $P$. nicotianae, with positive $F_{\text {IS }}$ values ranging from 0.260 to 1 (Table 3 ). This was particularly evident for isolates collected from Citrus spp. $\left(F_{\text {IS }}=0.721\right)$, which represented the most abundant group. MSN constructed using Bruvo's distance (Bruvo et al. 2004) revealed that isolates from Citrus constituted a distinct group regardless of their geographic origin (Figs. 1 and 2). Two subgroups, mainly represented by MLG48 (19 isolates) and MLG52 (38 isolates), were identified within the Citrus population. The first subgroup contained exclusively isolates from Vietnam, while the latter subgroup included isolates from three different continents (Europe, North America, and Asia) (Figs. 1 and 2). The only Citrus isolate outside of these groups was IMI268688 (MLG 89), which grouped close to the tobacco isolates from Kentucky and Virginia (MLG 76, 77, 83, 84, and 85). The A1 mating type occurred at high frequency ( 82 of 90) in Citrus spp. and the A2 isolates were mainly found in Vietnam (6 of 8). The PCA, based on Lynch's distance, further confirmed that isolates from Citrus spp. constituted a separate cluster, independent of geographic provenance (Fig. 3). In agreement between MSN and PCA, statistical analyses revealed a higher level of uniformity $\left(G^{\prime}=0.049, \mathrm{E}_{5}=0.4, F_{\text {IS }}=0.72\right)$ in the population from Citrus spp. (Table 3 ). Furthermore, $F_{\mathrm{ST}}$ values showed a relevant genetic divergence among Citrus isolates and other populations (Table 4).

A different population structure was observed for isolates from Nicotiana spp. These isolates clustered into three different groups (Fig. 1). Two of these groups were clearly associated with their geographic origin because they contained only isolates from Virginia and Kentucky (MLG 76, 77, 83, 84, and 85, all of which are A2 mating type) or Australia (MLG 78, 79, 80, 81, and 82; all except MLG82 were A1 mating type), respectively (Fig. 2). On the other hand, a third group (MLG 87, 88, 90, 91, 92, and 93; both A1 and A2 mating types) included isolates from Georgia, North Carolina, Kentucky, Virginia, and Greece (Fig. 2). According to the $G^{\prime}$ values observed, a significant lower genetic uniformity was determined in the Nicotiana population (0.714) as compared with the Citrus population. Furthermore, a higher level of variability was found based on $\mathrm{E}_{5}(0.896)$ and $F_{\text {IS }}(0.26)$ coefficients (Table 3 ).

Isolates from Lycopersicon spp. were predominantly A1 and were found to be more distantly related, with all but one (MLG 19) distributed in the central part of the network connected by thin gray lines, indicating a high genetic distance among isolates (Fig. 1). This is reflected by this population having the highest values of $G^{\prime}$ and $\mathrm{E}_{5}$ ( 0.833 and 0.952 , respectively) among those analyzed (Table 3 ). Furthermore, it had a significantly lower $F_{\text {IS }}(0.511)$ as compared with the Citrus population, indicating a lower level of inbreeding.

A high genetic diversity was revealed for isolates from some of the ornamental species. For example, the Lavandula population
(8 A1 and 14 A2 isolates) was separated into several genetically distant groups, despite the fact that all isolates were recovered from Italy (Figs. 1 and 2; Table 1). Similarly, isolates from genera Convolvulus and Myrtus (both with all A2 isolates) clustered into three and two genetically distant groups, respectively, although they were recovered from single nurseries located in Apulia and Sardinia, respectively. Statistical parameters confirmed a high level of genetic variation (Table 3 ). Genetically uniform populations were associated with isolates recovered from the ornamental species of Correa and Ruta (Fig. 1; Tables 3 and 4). However, this result was likely to be affected by the limited number of isolates examined (11 and 10 , respectively) and the fact that all isolates were recovered from the same nursery. Isolates from other plant genera were represented by a limited number of samples, preventing an accurate statistical analyses (Table 1). These isolates mainly scattered in the central part of the MSN (Fig. 1).

\section{DISCUSSION}

In the present study, a set of nine polymorphic microsatellite markers (Biasi et al. 2015) was used to analyze the genetic diversity within 231 isolates of $P$. nicotianae grouped into distinct populations representing a wide host range and several geographic locations. The selected markers proved to be very consistent, with a percentage of amplification close to $100 \%$; only 2 of 2,079 isolate-marker combinations did not produce an amplicon. In contrast, considerably higher levels of failures in sizing amplicons at SSR loci have been reported for other Phytophthora spp. For example, two of the nine loci selected for the assessment of the variability in $P$. infestans failed in producing positive amplification with $30 \%$ of the isolates (Brurberg et al. 2011). Our analyses further revealed a high level of polymorphism, with a total number of 4 (locus P2039) and 23 (locus P1509) alleles detected per locus. Unexpectedly, the number of bases in the repeat unit was not inversely correlated with the number of genotypes observed (Shinde et al. 2003). For example, the 4-bp motif analyzed in the present study (locus P5) yielded 16 different alleles and was more polymorphic than four other loci with a 3-bp motif. Dinucleotides were the markers with the highest number of alleles. On the whole, our data confirm that the selected markers were appropriate for the accurate characterization of populations of $P$. nicotianae. Furthermore, labeling primers for each locus with different fluorophores (HEX and FAM) significantly increased the throughput of the method and enabled fast, accurate, and costeffective genotyping (Biasi et al. 2015).

The genotyping of 231 isolates allowed identification of 99 MLG, with a significant number of isolates exhibiting a unique genetic fingerprint. Interestingly, an unexpected genetic framework for a diploid organism like $P$. nicotianae was revealed by the detection of 16 examples of triploidy and 1 of tetraploidy. The presence of polyploidy in $P$. nicotianae was previously observed by SNP analyses

TABLE 3. Origin, diversity statistics, and mating type frequency in Phytophthora nicotianae populations investigated in the present study ${ }^{\mathrm{a}}$

\begin{tabular}{lrrrrrrrr}
\hline & & & & & & & \multicolumn{3}{c}{ Mating type } \\
\cline { 6 - 9 } Population & $N$ & MLG & $G^{\prime}$ & $\mathrm{E}_{5}$ & $F_{\text {IS }}$ & A1 & A2 & ND \\
\hline Convolvulus & 9 & 5 & 0.429 & 0.859 & 0.464 & 0 & 9 & 0 \\
Lycopersicon & 10 & 9 & 0.833 & 0.952 & 0.511 & 1 & 7 & 2 \\
Ruta & 10 & 3 & 0.152 & 0.576 & 0.858 & 10 & 0 & 0 \\
Correa & 11 & 2 & 0.109 & 0.556 & 1 & 8 & 2 & 1 \\
Nicotiana & 20 & 17 & 0.714 & 0.896 & 0.260 & 7 & 12 & 1 \\
Lavandula & 23 & 12 & 0.365 & 0.832 & 0.369 & 8 & 14 & 1 \\
Myrtus & 37 & 13 & 0.129 & 0.614 & 0.624 & 0 & 37 & 0 \\
Citrus & 90 & 29 & 0.049 & 0.400 & 0.721 & 82 & 8 & 0 \\
\hline
\end{tabular}

a $N=$ number of isolates, MLG = number of multilocus genotypes identified in each population, $G^{\prime}=$ normalized Stoddart and Taylor's index, $\mathrm{E}_{5}=$ evenness, $F_{\text {IS }}=$ inbreeding coefficient, and ND = not determined. 
(Mammella et al. 2013). It is possible that this variation in ploidy was generated through sexual recombination because non-Mendelian recombination patterns in progeny have been reported (Förster and Coffey 1990). The characterization of $P$. cinnamomi using microsatellite markers also revealed a large proportion of non-Mendelian inheritance (Dobrowolski et al. 2002). This aberrant nuclear genetic condition was best explained by nondisjunction at meiosis in the trisomic parents, because aneuploid progeny were also identified. Ivors et al. (2006) observed conditions of trisomy for some isolates of $P$. ramorum. Initially, they hypothesized that multiple alleles resulted from horizontal gene transfer occurring after introgression of genes from other Phytophthora spp.; however, the high homology of flanking regions suggested that trisomy was due to gene duplication. Examples of different levels of ploidy for SSR regions were also documented for P. infestans (Brurberg et al. 2011; Goss et al. 2014; Lees et al. 2006; van der Lee et al. 2001). In the present study, Bruvo's distances were utilized to construct MSN and evaluated for 14 or 15 populations identified according to the genera of the plant hosts or geographic origin. The use of this function was important because it enabled calculation of genetic distances without considering ploidy of a locus and, thus, permitted interpretation of heterogeneous data (Cooke et al. 2012).

Analyses revealed significant differences in the structure of populations associated with different host species, although a prevalence of clonality was observed for all populations. Furthermore, the most abundant MLG detected were associated with a single host genus, suggesting a strong association among $P$. nicotianae genotypes and select plant hosts. According to both MSN and PCA analyses, Citrus isolates clustered together regardless of their geographic origin. In agreement with this clustering, all indexes used for statistical analyses confirmed a higher genetic uniformity in this group. This Citrus population was characterized by a low evenness $\left(E_{5}\right)$ value and by a heterozygote deficiency, especially when compared with other populations. Furthermore, the index of association $\left(F_{\mathrm{ST}}\right)$ confirmed a clear separation of the Citrus population that maintained its own genotypic uniqueness. These results are

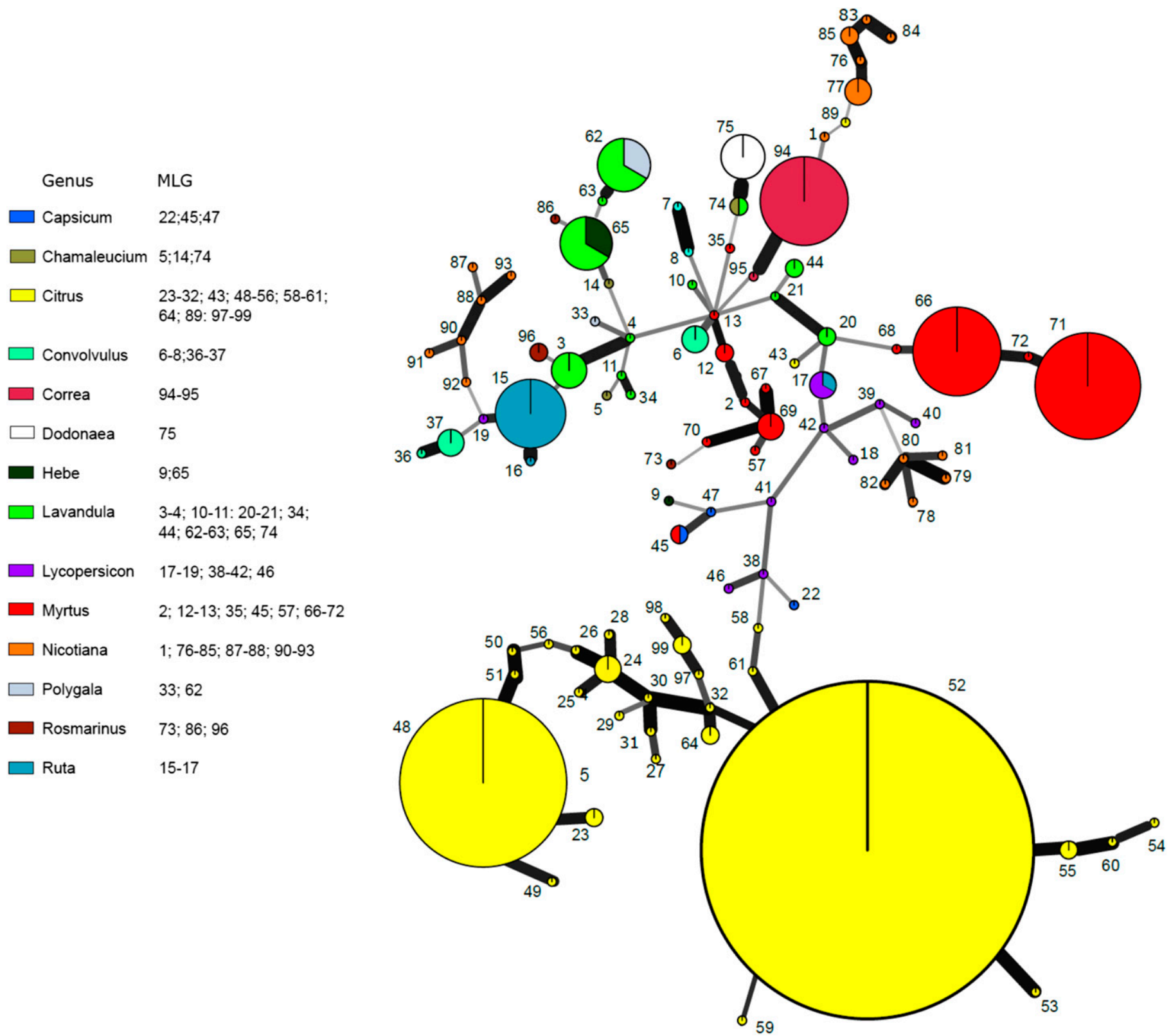

Fig. 1. Minimum spanning network of Phytophthora nicotianae isolates describing the relationship among multilocus genotypes (MLG) detected based on their host genus. Numbers along nodes and genus of origin correspond to MLG. Nodes represent unique MLG and are scaled proportionally to the number of individuals sharing the same MLG. Thickness and black intensity of lines connecting nodes are inversely proportional to Bruvo's distance (the larger the distance between two nodes, the thinner and less black intense is the line that connects them). 
particularly relevant considering that Citrus isolates were recovered from several different countries and represented the most abundant population analyzed in the present study. Our results are in agreement with previous reports based on the analysis of mitochondrial and nuclear SNP (Mammella et al. 2011, 2013). In this study, the majority of Citrus isolates from Italy, California, Florida, Syria, Albania, and the Philippines clustered in the same mitochondrial group and shared at least one nuclear allele. The existence of a marked preference among certain P. nicotianae genotypes for Citrus spp. is in agreement with the great degree of virulence specialization seen in $P$. nicotianae to a given host (Erwin and Ribeiro 1996). For instance, an isolate from okra was not pathogenic to Citrus spp. and vice versa (Erwin 1964). Similarly, isolates from Citrus spp. were more virulent on roots of rough lemon than isolates from petunia, tomato, walnut, silk tree, jojoba, hibiscus, and peach, although, in another study, tomato plants exhibited high susceptibility to many isolates, including Citrus isolates (Bonnet et al. 1978; Matheron and Matejka 1990). Furthermore, a mating type (A1) was largely prevalent on Citrus, although six and two isolates with A2 mating type were recovered in Vietnam and Italy, respectively. The absence of a geographic clustering and the concurrent existence of a significant correlation with the host could be indicative of extensive migration of the isolates via plant material or host adaptation. It can be speculated that $P$. nicotianae isolates have been spread worldwide with infected plant material and, afterward, lineages may have progressively diverged. In this context, a major role seems to be played by the globalization of the nursery trade, with particular emphasis on container-grown and bare root plants.

The identification of two subgroups within the Citrus population may also be related to the considerations discussed above. Indeed, one of the subgroups was represented by isolates exclusively recovered from Vietnam, mainly from Citrus maxima, while the other subgroup comprised isolates from several different countries and Citrus spp. Considering that $C$. maxima (commonly named "pommelo") is a native species of Southeast Asia and that the introduction of plant material of this species into Vietnam from other countries is very limited, a specific coevolution of P. nicotianae with Citrus in Vietnam

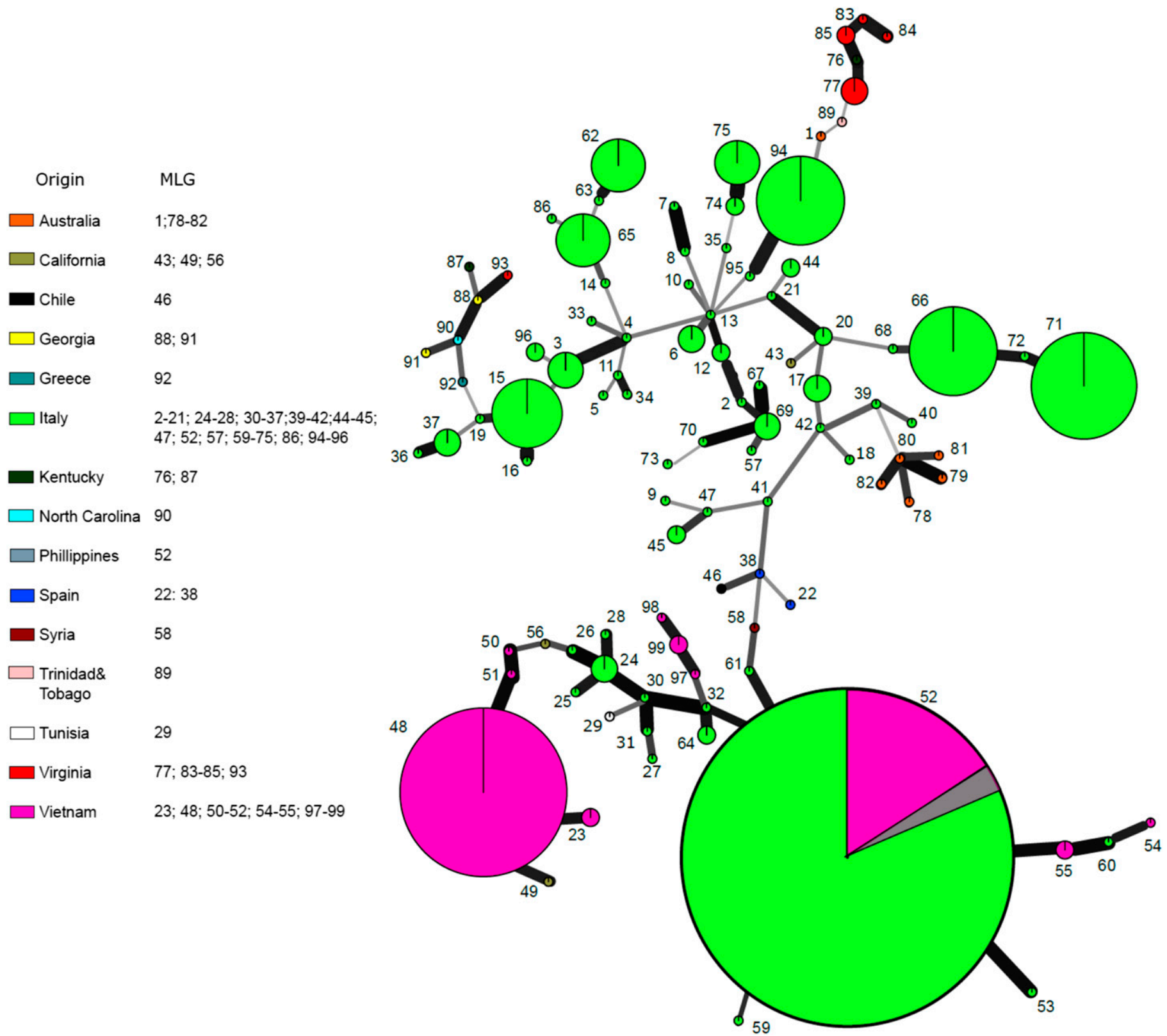

Fig. 2. Minimum spanning network of Phytophthora nicotianae isolates describing the relationship among multilocus genotypes (MLG) detected based on their country of origin. Numbers along nodes and country of origin correspond to MLG. Nodes represent unique MLG and are scaled proportionally to the number of individuals sharing the same MLG. Thickness and black intensity of lines connecting nodes are inversely proportional to Bruvo's distance (the larger the distance between two nodes, the thinner and less black intense is the line that connects them). 
can be hypothesized. An understanding of this phenomenon could allow unraveling of the molecular basis of interactions between host and $P$. nicotianae, developing a picture of how life history traits of both host and pathogen interaction shape evolutionary trajectories (Burdon and Thrall 2009).

A marked association among molecular groups and host of recovery was also revealed for isolates from Nicotiana, although a different population structure was observed. Indeed, isolates clustered into three genetically distinct groups, generally corresponding to different geographic areas and, in agreement with the presence of both mating types (7 A1 and 12 A2 isolates), a significantly lower genetic uniformity was revealed. Although a preferential virulence association between Nicotiana spp. and P. nicotianae has been reported (Colas et al. 1998), the commercial production system utilized for this crop is likely to have played a role in determining its geographical structuring. In fact, tobacco is propagated by seed, which does not contribute to the spread of the pathogen, and plantlets are very rarely transplanted into areas different from those in which they have been produced. In this situation, different pathogen lineages can evolve into geographically separated areas on their own host because migration does not play a factor. Furthermore, the tobacco population may have been shaped by cultivar resistance and other control means. According to Sullivan and coworkers (2005), the continuous planting of varieties with $P h p$ and $P h l$ genes caused a shift in pathogen population from race 0 to race 1 . On the other hand, prolonged cultivation of varieties with partial resistance to all races may cause an increased level of pathogen aggressiveness (Sullivan et al. 2005). Similarly, cultural practices, crop rotation, and chemicals commonly used in integrated control approaches have an impact on pathogen fitness and play a role in modeling populations (Bittner and Mila 2016).

A similar situation may occur for isolates from Lycopersicon. Indeed, isolates characterized in the present study were found to be genetically related, although high genetic variation was revealed within this population. Because tomato is propagated via seed and transplants produced in nurseries are generally utilized in the same area of production, the geographic isolation of lineages and their separate coevolution with the host can be hypothesized.

High levels of genetic variation and low inbreeding coefficients were observed for three of the analyzed populations from potted ornamental species in nurseries (Lavandula, Convolvulus, and Myrtus spp.). Although statistical analyses did not support a higher variability when compared with Nicotiana and Lycopersicon populations, it must be highlighted that isolates from these ornamental species were recovered from limited areas represented by few nurseries in Italy (Lavandula) or even single nurseries (Convolvulus and Myrtus). The prevalence or the exclusive presence of the A2 mating type in these populations deserves further investigation. Furthermore, the high genetic uniformity revealed in two other ornamental genera (Correa and Ruta) does not seem remarkable because of the limited number of isolates, all recovered from the same nurseries. The production system of nursery ornamentals is different from that of Citrus plants. Usually, Citrus plants produced in nurseries are planted in commercial orchards. In contrast, potted ornamental plants are produced in large production nurseries and then distributed to smaller ones which, in turn, sell them to retail garden centers or shops. As a consequence, new Phytophthora genotypes are rapidly spread on a large scale. Several components may determine the genetic variability of a pathogen population, including the genetic variability of the original population or the introduction of a few new genotypes from other populations (founder effect), mutations, selection pressure by the host, and sexual recombination. In ornamental nurseries, the cultivation of many plant species and varieties from different geographic areas may favor the introduction of exotic new Phytophthora spp., as demonstrated for P. ramorum (Goss et al. 2009; Ivors et al. 2006; Vercauteren et al. 2011), and the intermixing of complementary mating types of heterothallic species, thus increasing the

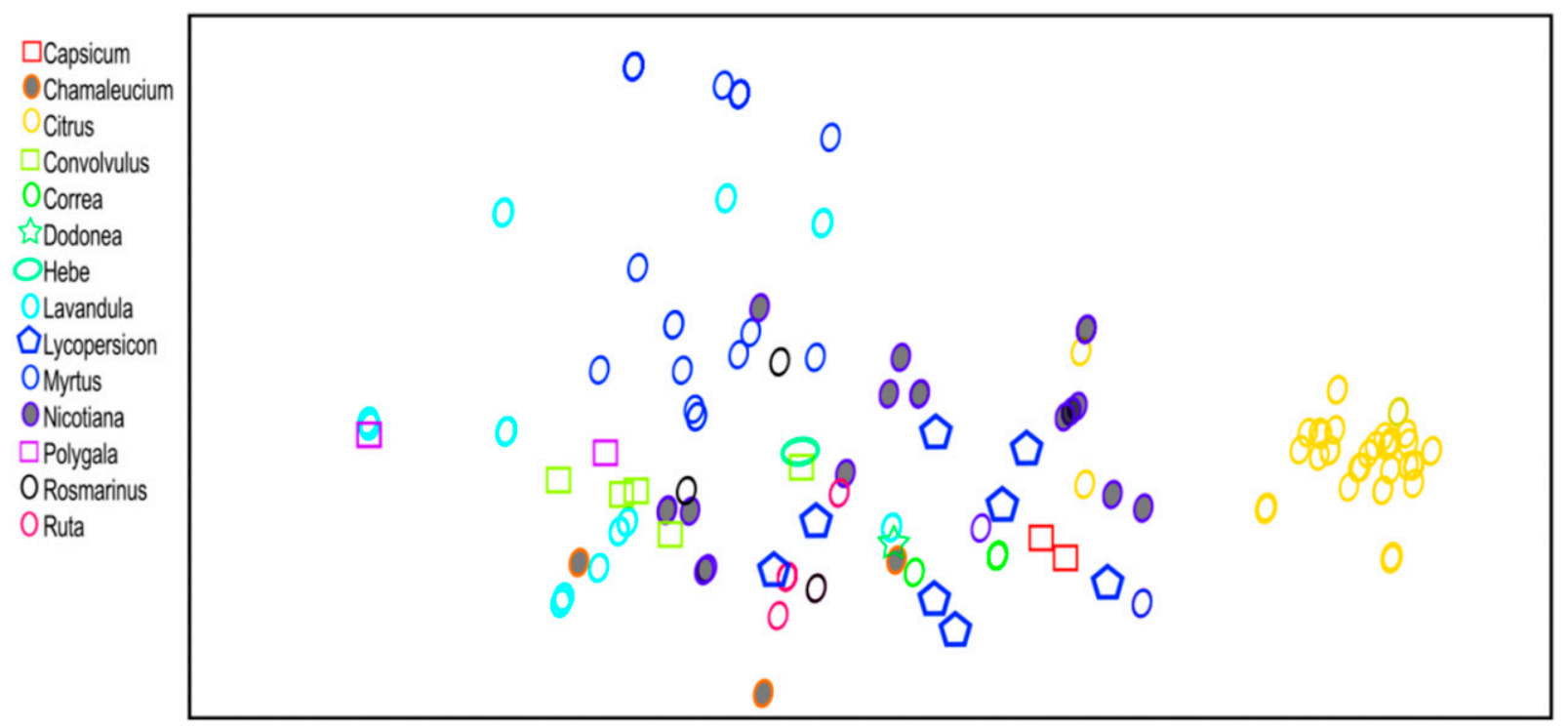

Fig. 3. Principal coordinate analysis based on Lynch distances of Phytophthora nicotianae isolates analyzed in the present study according to the host genus of origin.

TABLE 4. Genetic differentiation (pairwise $F_{\mathrm{ST}}$ ) estimates of simple-sequence repeats for Phytophthora nicotianae isolates grouped by host genus

\begin{tabular}{|c|c|c|c|c|c|c|c|c|}
\hline Host & Citrus & Convolvulus & Correa & Lavandula & Lycopersicon & Myrtus & Nicotiana & Ruta \\
\hline Citrus & $\ldots$ & $\ldots$ & $\ldots$ & $\ldots$ & $\ldots$ & $\ldots$ & $\ldots$ & $\ldots$ \\
\hline Convolvulus & 0.138 & $\ldots$ & $\ldots$ & $\ldots$ & $\ldots$ & $\ldots$ & $\ldots$ & $\ldots$ \\
\hline Correa & 0.073 & 0.25 & $\ldots$ & $\ldots$ & $\ldots$ & $\ldots$ & $\ldots$ & $\ldots$ \\
\hline Lavandula & 0.090 & 0.023 & 0.059 & $\ldots$ & $\ldots$ & $\ldots$ & $\ldots$ & $\ldots$ \\
\hline Lycopersicon & 0.116 & 0.037 & 0.058 & 0.037 & $\ldots$ & $\ldots$ & $\ldots$ & $\ldots$ \\
\hline Myrtus & 0.085 & 0.053 & 0.084 & 0.041 & 0.067 & $\ldots$ & $\ldots$ & $\ldots$ \\
\hline Nicotiana & 0.094 & 0.051 & 0.066 & 0.042 & 0.051 & 0.059 & $\ldots$ & $\ldots$ \\
\hline Ruta & 0.125 & 0.060 & 0.087 & 0.048 & 0.043 & 0.087 & 0.073 & $\ldots$ \\
\hline
\end{tabular}


opportunity of sexual recombination. Furthermore, interspecific hybrids of $P$. nicotianae are well documented (Faedda et al. 2013). Natural hybrids of $P$. nicotianae and $P$. cactorum were first reported in The Netherlands and they are now considered well established on several hosts all over the world (Faedda et al. 2013; Man in't Veld et al. 1998; Szigethy et al. 2013).

In agreement with the above considerations, the few MLG shared by isolates from different plant hosts were detected in isolates from the ornamental species (Polygala and Lavandula, Hebe and Lavandula, and Chamaleucium and Lavandula) or in isolates from ornamental and horticultural species (Ruta and Lycopersicon or Myrtus and Capsicum). Furthermore, considering the total number of analyzed isolates, a conspicuously higher number of MLG was found in nurseries as compared with Citrus and tobacco.

In conclusion, the present study provides an important advancement in our understanding of the population structure and evolutionary history of $P$. nicotianae. Although new analyses focusing on specific hosts and on a larger number of isolates collected with a hierarchical approach are necessary to accurately define $P$. nicotianae genetic groups, a strong association among pathogen genotypes and host species is clearly supported, suggesting that the speciation process of this pathogen may be driven by host selection pressure and type of propagation. In general, it seems that host specialization of a $P$. nicotianae population occurs more frequently in intensive cropping systems. This finding, in agreement with the data available on the host-specific virulence of $P$. nicotianae isolates (Erwin and Ribeiro 1996; Taylor et al. 2012) and with previous molecular data (Mammella et al. 2011, 2013), may suggest the need for reconsideration of the concept of species and the consequent identification of specific pathotypes or subspecies within P. nicotianae sensu lato. Genome-wide analyses currently in progress on several $P$. nicotianae strains of diverse origins may greatly contribute to enabling a comparative analysis of genes that determine host range (Kamoun et al. 2015). An analysis of the corresponding pathogenicity and virulence gene diversity may provide additional information necessary to draw firmer conclusions about factors involved in host specialization.

\section{ACKNOWLEDGMENTS}

We thank B. Tyler, F. Panabières, and C. Russ for making available the P. nicotianae genome sequences at https://olive.broadinstitute.org/projects/ phytophthora_parasitica prior to publication. Much of this work was conducted by A. Biasi while visiting the Martin lab and partially supported by a grant from the California Department of Food and Agriculture (2012 California Specialty Crop Block Grant Program SCB12051) and by grant FIRB 2010 (RBFR10PZ4N) from the Italian Ministry of Education, University and Research. We thank Z. Kamvar for guidance in using poppr and $\mathrm{R}$ for population genetic analysis.

\section{LITERATURE CITED}

Abad, Z. G., Abad, J. A., Cacciola, S. O., Pane, A., Faedda, R., Moralejo, E., Pérez-Sierra, A., Abad-Campos, P., Alvarez-Bernaola, L., Bakonyi, J., Józsa, A., Herrero, M. L., Burgess, T. I., Cunnington, J. H., Smith, I. W., Balci, Y., Blomquist, C., Henricot, B., Denton, G., Spies, C., McLeod, A., Belbahri, L., Cooke, D. E. L., Kageyama, K., Uematsu, S., Kurbetli, I., and Değirmenci, K. 2014. Phytophthora niederhauserii sp. nov., a new polyphagous species mostly isolated from ornamentals potted plants in twelve countries of five continents. Mycologia 106:431-447.

Biasi, A., Martin, F. N., and Schena, L. 2015. Identification and validation of polymorphic microsatellite loci for the analysis of Phytophthora nicotianae populations. J. Microbiol. Methods 110:61-67.

Bittner, R. J., and Mila, A. L. 2016. Effects of oxathiapiprolin on Phytophthora nicotianae, the causal agent of black shank of tobacco. Crop Prot. 81: 57-64.

Bonnet, P., Maia, N., Tello-Marquina, J., and Venard, P. 1978. Pouvoir pathogène du Phytophthora parasitica (Dastur): Facteurs de variabilité et notion de spécialisation parasitaire. Ann. Phytopathol. 2:15-29.

Brasier, C. M. 2008. The biosecurity threat to the UK and global environment from international trade in plants. Plant Pathol. 57:792-808.
Brownstein, M. J., Carpten, J. D., and Smith, J. R. 1996. Modulation of nontemplated nucleotide addition by Taq DNA polymerase: Primer modifications that facilitate genotyping. Biotechniques 20:1004-6, 1008-10.

Brurberg, M. B., Elameen, A., Le, V. H., Nærstad, R., Hermansen, A., Lehtinen, A., Hannukkala, A., Nielsen, B., Hansen, J., Andersson, B., and Yuen, J. 2011. Genetic analysis of Phytophthora infestans populations in the Nordic European countries reveals high genetic variability. Fungal Biol. 115: 335-342.

Bruvo, R., Michiels, N. K., D'Souza, T. G., and Schulenburg, H. 2004. A simple method for the calculation of microsatellite genotype distances irrespective of ploidy level. Mol. Ecol. 13:2101-2106.

Burdon, J. J., and Thrall, P. H. 2009. Coevolution of plants and their pathogens in natural habitats. Science 324:755-756.

Cacciola, S. O., Agosteo, G. E., Pennisi, A. M., Pane, A., and Pappalardo, P. 2001. Phytophthora species in nurseries of ornamental plants in southern Italy. J. Plant Pathol. 83:231-235.

Cacciola, S. O., Pane, A., and Magnano di San Lio, G. 1997. Identification and quantitative determination of Phytophthora species infecting ornamental plants in nurseries. Pages 483-485 in: Diagnosis and Identification of Plant Pathogens. H. W. Dehne, G. Adam, M. Diekman, J. Frahm, A. Mauler-Machnik, and P. van Halteren, eds. Kluwer Academic Publishers, Dordrecht, The Netherlands.

Chen, R. S., Boeger, J. M., and McDonald, B. A. 1994. Genetic stability in a population of a plant pathogenic fungus over time. Mol. Ecol. 3:209-218.

Clark, L. V., and Jasieniuk, M. 2011. POLYSAT: An R package for polyploidy microsatellite analysis. Mol. Ecol. Resour. 11:562-566.

Cline, E. T., Farr, D. F., and Rossman, A. Y. 2008. A synopsis of Phytophthora with accurate scientific names, host range, and geographic distribution. Online publication. Plant Health Prog. doi:10.1094/PHP-2008-0318-01RS

Colas, V., Lacourt, I., Ricci, P., Vanlerberghe-Masutti, F., Venard, P., Poupet, A., and Panabières, F. 1998. Diversity of virulence in Phytophthora parasitica on tobacco, as reflected by nuclear RFLPs. Phytopathology 88:205-212.

Cooke, D. E. L., and Lees, A. K. 2004. Markers, old and new, for examining Phytophthora infestans diversity. Plant Pathol. 53:692-704.

Cooke, D. E. L., Lees, A. K., Lasses, P., and Gronbech-Hansen, J. 2012. Making sense of Phytophthora infestans diversity at national and international scales. Pages 37-44 in: Proc. Thirteenth EuroBlight Workshop, St Petersburg, Russia.

Dobrowolski, M. P., Tommerup, I. C., Blakeman, H. D., and O'Brien, P. A. 2002. Non- Mendelian inheritance revealed in a genetic analysis of sexual progeny of Phytophthora cinnamomi with microsatellite markers. Fungal Genet. Biol. 35:197-212.

Erwin, D. C. 1964. A strain of Phytophthora parasitica from okra and its sexual compatibility with isolates from citrus. Phytopathology 54:114-115.

Erwin, D. C., and Ribeiro, O. K. 1996. Phytophthora Diseases Worldwide. American Phytopathological Society Press, St. Paul, MN.

Faedda, R., Cacciola, S. O., Pane, A., Szigethy, A., Bakonyi, J., Man in't Veld, W., Martini, P., Schena, L., and Magnano di San Lio, G. 2013. Phytophthora $\times$ pelgrandis causes root and collar rot of Lavandula stoechas in Italy. Plant Dis. 97:1091-1096.

Förster, H., and Coffey, M. D. 1990. Mating behavior of Phytophthora parasitica: Evidence for sexual recombination in oospores using DNA restriction fragment length polymorphisms as genetic markers. Exp. Mycol. 14:351-359.

Garnica, D. P., Pinzón, A. M., Quesada-Ocampo, L. M., Bernal, A. J., Barreto, E., Grünwald, N. J., and Restrepo, S. 2006. Survey and analysis of microsatellites from transcript sequences in Phytophthora species: Frequency, distribution, and potential as markers for the genus. BMC Genomics 7:245.

Gonthier, P., Sillo, F., Lagostina, E., Roccotelli, A., Cacciola, S. O., Stenlid, J., and Garbelotto, M. 2015. Selection processes in simple sequence repeats suggest a correlation with their genomic location: Insights from a fungal model system. BMC Genomics 16:1107.

Goss, E. M., Larsen, M., Chastagner, G. A., Givens, D. R., and Grünwald, N. J. 2009. Population genetic analysis infers migration pathways of Phytophthora ramorum in US nurseries. PLoS Pathog. 5:e1000583.

Goss, E. M., Tabima, J. F., Cooke, D. E. L., Restrepo, S., Fry, W. E., Forbes, G. A., Fieland, V. J., Cardenas, M., and Grünwald, N. J. 2014. The Irish potato famine pathogen Phytophthora infestans originated in central Mexico rather than the Andes. Proc. Natl. Acad. Sci. USA 111:8791-8796.

Grünwald, N. J., Goodwin, S. B., Milgroom, M. G., and Fry, W. E. 2003. Analysis of genotypic diversity data for populations of microorganisms. Phytopathology 93:738-746.

Hu, J., Pang, Z., Bi, Y., Shao, J., Diao, Y., Guo, J., Liu, Y., Lu, H., Lamour, K., and Liu, X. 2013. Genetically diverse long-lived clonal lineages of Phytophthora capsici from pepper in Gansu, China. Phytopathology 103:920-926.

Ioos, R., Barrès, B., Andrieux, A., and Frey, P. 2007. Characterization of microsatellite markers in the interspecific hybrid Phytophthora alni ssp. alni, and cross-amplification with related taxa. Mol. Ecol. Notes 7:133-137. 
Ippolito, A., Schena, L., and Nigro, F. 2002. Detection of Phytophthora nicotianae and $P$. cytrophthora in citrus roots and soils by nested PCR. Eur. J. Plant Pathol. 108:855-868.

Ippolito, A., Schena, L., Nigro, F., Soleti Ligorio, V., and Yaseen, T. 2004. Real-time detection of Phytophthora nicotianae and P. citrophthora in citrus roots and soil. Eur. J. Plant Pathol. 110:833-843.

Ivors, K., Garbelotto, M., Vries, I. D. E., Ruyter-Spira, C., Hekkert, B. T., Rosenzweig, N., and Bonants, P. 2006. Microsatellite markers identify three lineages o f Phytophthora ramorum in US nurseries, yet single lineages in US forest and European nursery populations. Mol. Ecol. 15: 1493-1505.

Johnson, E. S., Wolff, M. F., Wernsman, E. A., and Rufty, R. C. 2002a. Marker-assisted selection for resistance to black shank disease in tobacco. Plant Dis. 86:1303-1309.

Jung, T., Orlikowski, L., Henricot, B., Abad-Campos, P., Aday, G., Aguín Casal, O., Bakony, J., Cacciola, S. O., Cech, T., Chavarriaga, D., Corcobado, T., Cravador, A., Decourcelle, T., Denton, G., Diamandis, S., Doğmuş-Lehtijärvi, H. T., Franceschini, A., Ginetti, B., Green, S., Glavendekić, M., Hantula, J., Hartmann, G., Herrero, M., Ivic, D., Horta Jung, M., Lilja, A., Keca, N., Kramarets, V., Lyubenova, A., Machado, H., Magnano di San Lio, G., Mansilla Vázquez, P. J., Marçais, B., Matsiakh, I., Milenkovic, I., Moricca, S., Nagy, Z. Á., Nechwatal, J., Olsson, C., Oszako, T., Pane, A., Paplomatas, E. J., Pintos Varela, C., Prospero, S., Rial Martínez, C., Rigling, D., Robin, C., Rytkönen, A., Sánchez, M. E., Sanz Ros, A. V., Scanu, B., Schlenzig, A., Schumacher, J., Slavov, S., Soll, A., Sousa, E., Stenlid, J., Talgø, V., Tomic, Z., Tsopelas, P., Vannini, A., Vettraino, A. M., Wenneker, M., Woodward, S., and Peréz-Sierra, A. 2016. Widespread Phytophthora infestations in European nurseries put forest, semi-natural and horticultural ecosystems at high risk of Phytophthora diseases. For. Pathol. 46:134-163.

Kamoun, S., Furzer, O., Jones, J. D. G., Judelson, H. S., Ali, G. S., Dalio, R. J. D., Roy, S. G., Schena, L., Zambounis, A., Panabieres, F., Cahill, D., Ruocco, M., Figueiredo, A., Chen, X.-R., Hulvey, J., Stam, R., Lamour, K., Gijzen, M., Tyler, B. M., Grünwald, N. J., Mukhtar, M. S., Tome, D. F. A., Tor, M., Van den Ackerveken, G., McDowell, J., Daayf, F., Fry, W. E., Lindqvist-Kreuze, H., Meijer, H. J. G., Petre, B., Ristaino, J., Yoshida, K., Birch, P. R. J., and Govers, F. 2015. The top 10 oomycete pathogens in molecular plant pathology. Mol. Plant Pathol. 16:413-434.

Kamvar, Z. N., Tabima, J. F., and Grünwald, N. J. 2014. Poppr: An R package for genetic analysis of populations with clonal, partially clonal, and/or sexual reproduction. PeerJ 2:e281.

Lamour, K. H., Daughtrey, M. L., Benson, D. M., Hwang, J., and Hausbeck, M. K. 2003. Etiology of Phytophthora drechsleri and P. nicotianae $(=P$. parasitica $)$ diseases affecting floriculture crops. Plant Dis. 87:854-858.

Lees, A. K., Wattier, R., Shaw, D. S., Sullivan, L., Williams, N. A., and Cooke, D. E. L. 2006. Novel microsatellite markers for the analysis of Phytophthora infestans populations. Plant Pathol. 55:311-319.

Li, Y., Cooke, D. E. L., Jacobsen, E., and van der Lee, T. 2013. Efficient multiplex simple sequence repeat genotyping of the oomycete plant pathogen Phytophthora infestans. J. Microbiol. Methods 92:316-322.

Lynch, M. 1990. The similarity index and DNA fingerprinting. Mol. Biol. Evol. 7:478-484

Mammella, M. A., Cacciola, S. O., Martin, F., and Schena, L. 2011. Genetic characterization of Phytophthora nicotianae by the analysis of polymorphic regions of the mitochondrial DNA. Fungal Biol. 115:432-442.

Mammella, M. A., Martin, F. N., Cacciola, S. O., Coffey, M. D., Faedda, R., and Schena, L. 2013. Analyses of the population structure in a global collection of Phytophthora nicotianae isolates inferred from mitochondrial and nuclear DNA sequences. Phytopathology 103:610-622.

Man in't Veld, W. A., Veenbaas-Rijks, W. J., Ilieva, E., de Cock, A. W. A. M., Bonants, P. J. M., and Pieters, R. 1998. Natural hybrids of Phytophthora nicotianae and $P$. cactorum demonstrated by isozyme analysis and random amplified polymorphic DNA. Phytopathology 88:922-929.

Matheron, M. E., and Matejka, J. C. 1990. Differential virulence of Phytophthora parasitica recovered from citrus and other plants to rough lemon and tomato. Plant Dis. 74:138-140.

Meirmans, P. G., and van Tienderen, P. H. 2004. GENOTYPE and GENODIVE: Two programs for the analysis genetic diversity of asexual organisms. Mol. Ecol. Notes 4:792-794.

Moralejo, E., Pérez-Sierra, A. M., Álvarez, L. A., Belbahri, L., Lefort, F., and Descals, E. 2009. Multiple alien Phytophthora taxa discovered on diseased ornamental plants in Spain. Plant Pathol. 58:100-110.

Oliveira, E. J., Padua, J. G., Zucchi, M. I., Vencovsky, R., and Carneiro Vieira, M. L. 2006. Origin, evolution and genome distribution of microsatellites. Genet. Mol. Biol. 29:294-307.

Olson, H. A., and Benson, D. M. 2011. Characterization of Phytophthora spp. on floriculture crops in North Carolina. Plant Dis. 95:1013-1020.

Olson, H. A., Jeffers, S. N., Ivors, K. L., Steddom, K. C., Williams-Woodward, J. L., Mmbaga, M. T., Benson, D. M., and Hong, C. X. 2013. Diversity and mefenoxam sensitivity of Phytophthora spp. associated with the ornamental horticulture industry in the southeastern United States. Plant Dis. 97:86-92.

Panabières, F., Ali, G. S., Allagui, M. B., Dalio, R. J. D., Gudmestad, N. C., Kuhn, M. L., Roy, S. G., Schena, L., and Zampounis, A. 2016. Phytophthora nicotianae diseases worldwide: New knowledge of a long-recognised pathogen. Phytopathol. Mediterr. 55:20-40.

Pane, A., Martini, P., Chimento, A., Rapetti, S., Savona, S., Grasso, F. M., and Cacciola, S. O. 2005. Phytophthora species on ornamental plants in Italy. (Abstr.) J. Plant Pathol. 87:301.

Parke, J. L., and Grünwald, N. J. 2012. A systems approach for management of pests and pathogens of nursery crops. Plant Dis. 96:1236-1244.

Prigigallo, M. I., Abdelfattah, A., Cacciola, S. O., Faedda, R., Sanzani, S. M., Cooke, D. E. L., and Schena, L. 2016. Metabarcoding analysis of Phytophthora diversity using genus specific primers and 454 pyrosequencing. Phytopathology 106:305-313.

Prigigallo, M. I., Mosca, S., Cacciola, S. O., Cooke, D. E. L., and Schena, L. 2015. Molecular analysis of Phytophthora diversity in nursery-grown ornamental and fruit plants. Plant Pathol. 64:1308-1319.

Prospero, S., Hansen, E. M., Grünwald, N. J., and Winton, L. M. 2007. Population dynamics of the sudden oak death pathogen Phytophthora ramorum in Oregon from 2001 to 2004. Mol. Ecol. 16:2958-2973.

Reichard, S. H., and White, P. 2001. Horticulture as a pathway of invasive plant introductions in the United States. Bioscience 51:103-113.

Robideau, G. P., Arthur, W. A., De Cock, M., Coffey, M. D., Voglmayr, H., Brouwer, H., Bala, K., Chitty, D. W., Désaulniers, N., Eggertson, Q. A., Gachon, C. M. M., Hu, C. H., Kupper, F. C., Rintoul, T. L., Sarhan, E., Verstappen, E. C. P., Zhang, Y., Bonants, P. J. M., Ristaino, J. B., and Lévesque, A. 2011. DNA barcoding of oomycetes with cytochrome $c$ oxidase subunit I and internal transcribed spacer. Mol. Ecol. Resour. 11:1002-1011.

Ronquist, F., and Huelsenbeck, J. P. 2003. MrBayes 3: Bayesian phylogenetic inference under mixed models. Bioinformatics 19:1572-1574.

Salipante, S. J., and Hall, B. G. 2011. Inadequacies of Minimum Spanning Trees in Molecular Epidemiology. J. Clin. Microbiol. 49:3568-3575.

Schena, L., Cardle, L., and Cooke, D. E. L. 2008. Use of genome sequence data in the design and testing of SSR markers for Phytophthora species. BMC Genomics 9:620.

Schoebel, C. N., Jung, E., and Prospero, S. 2013. Development of new polymorphic microsatellite markers for three closely related plant-pathogenic Phytophthora species using 454-pyrosequencing and their potential applications. Phytopathology 103:1020-1027.

Schoebel, C. N., Stewart, J., Grünwald, N. J., Rigling, D., and Prospero, S. 2014. Population history and pathways of spread of the plant pathogen Phytophthora plurivora. PLoS One 9:e85368.

Shinde, D., Lai, Y., Sun, F., and Arnheim, N. 2003. Taq DNA polymerase slippage mutation rates measured by PCR and quasi-likelihood analysis: (CA/GT)n and (A/T)n microsatellites. Nucleic Acids Res. 31:974-980.

Stewart, S., Abeysekara, N., and Robertson, A. E. 2014. Pathotype and genetic shifts in a population of Phytophthora sojae under soybean cultivar rotation. Plant Dis. 98:614-624.

Stoddart, J. A., and Taylor, J. F. 1988. Genotypic diversity: Estimation and prediction in samples. Genetics 118:705-711.

Sullivan, M. J., Melton, T. A., and Shew, H. D. 2005. Managing the race structure of Phytophthora parasitica var. nicotianae with variety rotation. Plant Dis. 89:1285-1294.

Sullivan, M. J., Parks, E. J., Cubeta, M. A., Gallup, C. A., Melton, T. A., Moyer, J. W., and Shew, H. D. 2010. An assessment of the genetic diversity in a field population of Phytophthora nicotianae with a changing race structure. Plant Dis. 94:455-460.

Szigethy, A., Nagy, Z. Á., Vettraino, A. M., Józsa, A., Cacciola, S. O., Faedda, R., and Bakonyi, J. 2013. First report of Phytophthora $\times$ pelgrandis causing root rot and lower stem necrosis of common box, lavender and Port-Orfordcedar in Hungary. Plant Dis. 97:152.

Taylor, R. J., Pasche, J. S., Shew, H. D., Lannon, K. R., and Gudmestad, N. C. 2012. Tuber rot of potato caused by Phytophthora nicotianae: Isolate aggressiveness and cultivar susceptibility. Plant Dis. 96:693-704.

van der Lee, T., Robold, A., Testa, A., van't Klooster, J. W., and Govers, F. 2001. Mapping of avirulence genes in Phytophthora infestans with amplified fragment length polymorphism markers selected by bulked segregant analysis. Genetics 157:949-956.

Vercauteren, A., De Dobbelaere, I., Van Bockstaele, E., Maes, M., and Heungens, K. 2010. Genotypic and phenotypic characterization of the European A2 isolates of Phytophthora ramorum. Eur. J. Plant Pathol. 129:621-635.

Zhang, X. G., Sun, W. X., Guo, L., Yu, J. F., and Chang, C. J. 2003. Genetic and pathogenic variation among tobacco black shank strains of Phytophthora parasitica var. nicotianae from the main tobacco growing in China. J. Phytopathol. 151:259-266.

Zhang, X. G., Zheng, G. S., Han, H. Y., Han, W., Shi, C. K., and Chang, C. J. 2001. RAPD-PCR for diagnosis of Phytophthora parasitica var. nicotianae isolates which cause black shank on tobacco. J. Phytopathol. 149:569-574. 